\title{
Forced Arterial Suction Thrombectomy of Septic Embolic Middle Cerebral Artery Occlusion Due to Infective Endocarditis: an Illustrative Case and Review of the Literature
}

\author{
Jeong-Min Kim, MD', 5 , Ji-Su Jeon, MD', 5, Yong-Won Kim, MD1, 2, 4, 5, Dong-Hun Kang, MD 2, 3, 4, , \\ Yang-Ha Hwang, MD, PhD', 4, , Yong-Sun Kim, MD, PhD ${ }^{2,4}$
}

In acute ischemic stroke patients with major intracranial vessel occlusion due to infective endocarditis, treatment modalities are not well established. A 40-year-old woman presented with acute stroke due to left middle cerebral artery occlusion. She was successfully treated with intra-arterial mechanical thrombectomy, and the subsequent clinical outcome was favorable. Pathological analysis of the retrieved clots showed septic thrombi containing gram-positive cocci. Based on literature review and the present case regarding treatment strategies for patients with septic embolic stroke, pharmacological thrombolysis might increase the risk of hemorrhagic complications, which might alter clinical outcome. Therefore, we can consider intra-arterial mechanical thrombectomy as a first-line treatment option in patients with acute stroke resulting from infective endocarditis.

Key Words : Mechanical thrombectomy; Thrombolysis; Infective endocarditis; Acute ischemic stroke

The restoration of antegrade perfusion following acute ischemic stroke with a large vessel occlusion is associated with better clinical outcomes and reduced

\footnotetext{
Departments of Neurology ${ }^{1}$, Radiology $^{2}$, Neurosurgery ${ }^{3}$ and Cerebrovascular Center ${ }^{4}$, Kyungpook National University Hospital, Daegu, Korea

School of Medicine ${ }^{5}$, Kyungpook National University, Daegu, Korea Received July 15, 2014; accepted after revision July 21, 2014. Correspondence to: Yang-Ha Hwang, MD, PhD, Assistant Professor, School of Medicine, Kyungpook National University, Department of Neurology and Cerebrovascular Center, Kyungpook National University Hospital, 130, Dongduk-ro, Jung-gu, Daegu 700721 , Korea.

Tel. 82.53.420.5758 Fax. 82.53.422.4265

E-mail: yangha.hwang@gmail.com

This is an Open Access article distributed under the terms of the Creative Commons Attribution Non-Commercial License (http://creativecommons.org/licenses/by-nc/3.0) which permits unrestricted non-commercial use, distribution, and reproduction in any medium, provided the original work is properly cited.
}

mortality. However, in the case of stroke caused by infective endocarditis, the safety and efficacy of intravenous and/or intra-arterial (IA) thrombolytic therapy is not well established in the literature, and there are some reports of an increased risk of intracerebral hemorrhage (ICH) [1, 2]. So, clinicians sought alternative methods for revascularization, and mechanical thrombectomy alone using up-to-date devices might have outcomes at least as good, and without a risk of $\mathrm{ICH}$, but there are few case reports to support this claim [3-5]. We herein describe a case of acute middle cerebral artery (MCA) occlusion due to infective endocarditis, which was successfully treated with IA mechanical thrombectomy using the forced arterial suction thrombectomy (FAST) technique [6]. We also present pathologic findings of the retrieved clots and we review currently available literature on this issue. 


\section{CASE REPORT}

A 40-year-old right-handed woman presented with fever and general malaise for a few days. During her hospital stay, she was found to be aphasic and right hemiparetic by her husband, and he notified our on-call Neurology resident. She was febrile $\left(37.6^{\circ} \mathrm{C}\right)$, blood pressure was $140 / 80 \mathrm{~mm} \mathrm{Hg}$, and her pulse was regular (120 bpm). The initial neurological examination revealed expressive aphasia, right homonymous hemianopia, and right hemiparesis including facial paresis with a National Institutes of Health Stroke Scale (NIHSS) score of 15. An electrocardiogram showed sinus tachycardia without $\mathrm{T}$ wave changes. The white blood cell count was $15,410 / \mu \mathrm{L}$, the erythrocyte sedimentation rate was $48 \mathrm{~mm} / \mathrm{hr}$ and the C-reactive protein level was $3.93 \mathrm{mg} / \mathrm{dL}$. Systolic murmur could be heard in the apex area. A diffusion-weighted image revealed subtle early ischemic changes in the periinsular area, and a perfusion-weighted image showed mean transition time delays on the left MCA M2 inferior trunk territory (Fig. 1A, B), and magnetic resonance angiography showed a left MCA M1 cut-off sign (Fig. 1C). IA mechanical thrombectomy using the FAST technique was performed on the left MCA occlusion after 5 hours from symptom onset (Fig. 1E). The procedure was initiated by placing the coaxialguiding system into the internal carotid artery, and then the $041 \mathrm{~F}$ Penumbra reperfusion catheter (Penumbra Inc., Alameda, CA, USA) was advanced to the area of occlusion over a 1.7 F microcatheter (Excelsior SL-10;

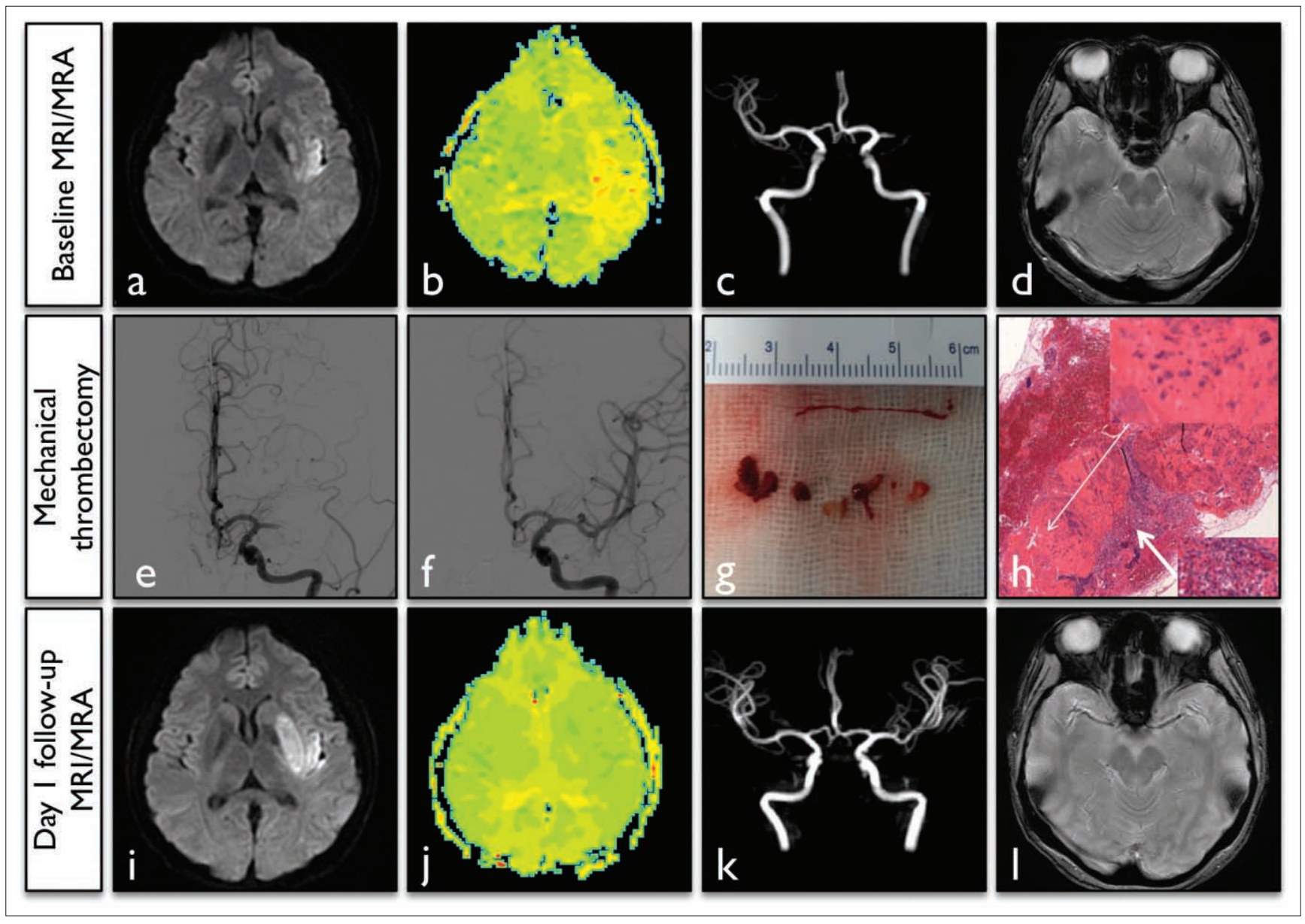

Fig. 1. Summary of brain images and angiographic findings in a 40-year-old woman. A-C. Initial magnetic resonance image and angiography showed acute ischemic change in the left peri-insula area, delayed mean transition time of the left MCA partial territory and a left MCA M1 occlusion. D. The initial gradient-echo image showed a susceptibility vessel sign (arrowhead) in the left MCA. E, F. Cerebral angiography showed a left MCA occlusion at pre-treatment and complete recanalization at post-treatment. G. A gross image of retrieved multiple clots ranging from 3 to $7 \mathrm{~mm}$. H. Microscopic image with hematoxylin and eosin staining, where original magnification $\times 40$ and $\times 400$ of thrombus pathology showed gram positive cocci (thin arrow) and inflammatory cells with fibrin deposition (thick arrow). I-L. In one day follow-up images, we found minimal extension of infarct volume with putamen, normalization of perfusion deficits, complete recanalization of the occluded artery and no susceptibility vessel sign. 
Table 1. Summary of Clinical and Angiographic Characteristics in Present and Previously Reported Case Series of Acute Ischemic Stroke Associated with Infective Endocarditis

\begin{tabular}{|c|c|c|c|c|c|c|c|c|}
\hline Case series & $\begin{array}{l}\text { Age/ } \\
\text { Sex }\end{array}$ & $\begin{array}{l}\text { Baseline } \\
\text { NIHSS } \\
\text { score }\end{array}$ & $\begin{array}{l}\text { Site of } \\
\text { occlusion }\end{array}$ & Treatment modalities & $\begin{array}{l}\text { Recanali- } \\
\text { zation }\end{array}$ & $\begin{array}{l}\text { Clinical } \\
\text { outcome }^{*}\end{array}$ & & $\mathrm{ICH}$ \\
\hline Siccoli, et al. 2003 [1] & $31 / F$ & 13 & BA & IA urokinase $750 \mathrm{k}$ IU & Yes & $\begin{array}{l}\text { NIHSS score } 5 \\
\text { at } 3 \text { weeks }\end{array}$ & Good & No \\
\hline Junna, et al. 2007 [1] & $56 / \mathrm{M}$ & 15 & Unknown & IV tPA & Unknown & $\begin{array}{l}\text { NIHSS score } 4 \\
\text { at } 48 \text { hours }\end{array}$ & Good & No \\
\hline Tan, et al. 2009 [1] & $12 / F$ & 18 & Left ICA-T & IA tPA $9 \mathrm{mg}$ & Yes & $\begin{array}{l}\text { NIHSS score } 5 \\
\text { at } 6 \text { weeks }\end{array}$ & Good & No \\
\hline Bhuva, et al. 2010 [2] & $46 / \mathrm{M}$ & 15 & $\begin{array}{l}\text { Right MCA } \\
\text { M1 }\end{array}$ & IV tPA & Yes & Expired & Poor & Yes \\
\hline Bhuva, et al. 2010 [2] & $65 / F$ & 21 & $\begin{array}{l}\text { Left MCA } \\
\text { M1 }\end{array}$ & IV tPA & No & Unknown & - & Yes \\
\hline Bhuva, et al. 2010 [2] & $67 / \mathrm{M}$ & 17 & Unknown & IV tPA & Unknown & Unknown & - & Yes \\
\hline Sontineni, et al. 2010 [1] & $70 / \mathrm{M}$ & 13 & Unknown & IV tPA & Unknown & $\begin{array}{l}\text { NIHSS score } 5 \\
\text { at } 6 \text { weeks }\end{array}$ & Good & No \\
\hline Ong, et al. 2013 [1] & $68 / \mathrm{M}$ & $12^{\star *}$ & $\begin{array}{l}\text { Left MCA } \\
\text { M2 }\end{array}$ & IV tPA & Yes & $\begin{array}{l}\text { NIHSS score } 1 \\
\text { at } 7 \text { months }\end{array}$ & Good & Yes \\
\hline Bain, et al. 2011 [10] & $24 \mathrm{~F}$ & 18 & Left ICA-T & $\begin{array}{l}\text { IA tPA } 4 \text { mg; } \\
\text { Mechanical thrombectomy; } \\
\text { Stent with balloon angioplasty }\end{array}$ & Yes & $\begin{array}{l}\text { NIHSS score } 2 \\
\text { at } 2 \text { months }\end{array}$ & Good & No \\
\hline Kang, et al. 2013 [12] & $39 / F$ & 16 & $\begin{array}{l}\text { Left MCA } \\
\text { M1 }\end{array}$ & $\begin{array}{l}\text { IA urokinase } 150 \mathrm{k} \mathrm{IU} \text {; } \\
\text { IA tirofiban } 0.1 \mathrm{mg} \text {; } \\
\text { Mechanical thrombectomy } \\
\text { (solitaire) }\end{array}$ & Yes & $\begin{array}{l}\text { NIHSS score } 3 \\
\text { at } 4 \text { weeks }\end{array}$ & Good & No \\
\hline Toeq, et al. 2014 [11] & $73 / \mathrm{M}$ & 20 & $\begin{array}{l}\text { Right } \\
\text { ICA-T }\end{array}$ & $\begin{array}{l}\text { IA tPA } 10 \mathrm{mg} \text {; } \\
\text { Mechanical thrombectomy } \\
\text { (stent retriever and aspiration } \\
\text { catheter) }\end{array}$ & Yes & $\begin{array}{l}\text { NIHSS score } 0 \\
\text { at } 8 \text { months }\end{array}$ & Good & No \\
\hline $\begin{array}{l}\text { Dababneh, et al. } \\
2012 \text { [3] }\end{array}$ & $67 / F$ & Unknown & $\begin{array}{l}\text { Left MCA } \\
\text { M1 }\end{array}$ & $\begin{array}{l}\text { Mechanical thrombectomy } \\
\text { (Penumbra) }\end{array}$ & Yes & Hospice care & Poor & No \\
\hline $\begin{array}{l}\text { Sukumaran, et al. } \\
2012[4]\end{array}$ & 33/M & 14 & $\begin{array}{l}\text { Left MCA } \\
\text { M1 }\end{array}$ & $\begin{array}{l}\text { Mechanical thrombectomy } \\
\text { (solitaire) }\end{array}$ & Yes & $\begin{array}{l}\text { NIHSS score } 0 \\
\text { at } 4 \text { days }\end{array}$ & Good & No \\
\hline Kan, et al. 2012 [5] & $78 / F$ & 16 & $\begin{array}{l}\text { Right } \\
\text { MCA M2 }\end{array}$ & $\begin{array}{l}\text { Mechanical thrombectomy } \\
\text { (solitaire) }\end{array}$ & Yes & $\begin{array}{l}\text { NIHSS score } \\
12 \text { at } 24 \text { hours }\end{array}$ & Poor & No \\
\hline Present case & $40 / F$ & 15 & $\begin{array}{l}\text { Left MCA } \\
\text { M1 }\end{array}$ & $\begin{array}{l}\text { Mechanical thrombectomy } \\
\text { (FAST) }\end{array}$ & Yes & $\begin{array}{l}\text { NIHSS score } 3 \\
\text { at } 3 \text { days }\end{array}$ & Good & No \\
\hline
\end{tabular}

Abbreviations: NIHSS, National Institute of Health Stroke Scale; ICH, intracerebral hemorrhage; BA, basilar artery; IA, intra-arterial; IU, international unit; IV, intravenous; tPA, tissue type plasminogen activator; ICA-T, internal carotid artery terminus; MCA, middle cerebral artery; FAST, forced arterial suction thrombectomy;

* Clinical outcomes were categorized into good, poor or unknown; good: post-treatment NIHSS score 5 or less without consideration of follow-up duration, poor: adverse events which prolonged hospitalization or post-treatment NIHSS score 6 or more without consideration of follow-up duration.

** NIHSS score of 22 at the time of treatment. 
Boston Scientific, Fremont, CA, USA) and microwire (synchro 14; Boston Scientific, Natick, MA, USA). After removal of the microcatheter and microwire, manual aspiration was performed with a $50 \mathrm{ml}$ syringe. The Penumbra reperfusion catheter was slowly withdrawn, while maintaining pulling forces [6]. A complete recanalization was achieved, and multiple fragmented clots were retrieved through the reperfusion catheter tip (Fig. 1F, G).

Pathologic analysis of the retrieved clots revealed septic thrombi containing gram-positive cocci (Fig. $1 \mathrm{H})$. Diagnosis of an infective endocarditis was confirmed thereafter using transthoracic echocardiography. It showed mitral valve vegetation and severe mitral valve regurgitation with valve perforation. Blood cultures were positive for streptococcus mitis. Intravenous antibiotic treatment was started with ceftriaxone and gentamicin. She recovered to mild right hemiparesis and mild expressive aphasia with an NIHSS score of 3 at 2 days after onset. She received a mitral valve replacement operation and vegetation removal. Valve biopsy was done, and it showed myxoid degeneration and vegetation. After the operation, oral anticoagulation was started for secondary prevention of stroke. Three months later, her modified Rankin Scale score was 2 . She still had mild language and calculation problems, but she could carry out almost activities of daily living.

\section{DISCUSSION}

Brain embolism constitutes the major complication of infective endocarditis. With an incidence rate of 20$40 \%$ in patients diagnosed with native-valve endocarditis, it manifests as ischemic stroke in most cases or hemorrhagic stroke in some cases [7, 8]. The mechanisms responsible for hemorrhagic stroke can be septic arteritis, mycotic aneurysms or secondary hemorrhagic transformations associated with anticoagulation [8]. The neurological outcome of septic embolic stroke largely depends on the severity of initial brain damage [9], and the mortality of septic embolic stroke was reported to be up to $56 \%$ from a hospital-based consecutive case series [7]. The main treatment for infective endocarditis is to institute effective antibiotic therapy as soon as possible to reduce the mortality and morbidity from embolic complications and heart failure. However, there has been no comparative research or consensus statement on how to manage ischemic stroke patients with large vessel occlusion due to infective endocarditis.
We reported successful recanalization with a favorable clinical outcome in a patient with acute ischemic stroke due to infective endocarditis, where the treatment was IA mechanical thrombectomy without any adjuvant thrombolytics. Table 1 summarized clinical and angiographic characteristics and outcomes of present and previous reported cases of acute ischemic stroke related to infective endocarditis based on treatment modalities [1-5, 10-12]. The use of thrombolytic agents only in such situations were reported in 8 cases in the literature [1,2]. However, the clinical outcomes were diverse and not reported in some cases. Also, about a half of the patients suffered intracerebral hemorrhage, which might be associated with the use of thrombolytics or pre-existing mycotic aneurysms $[1,2]$. On the contrary, the use of mechanical thrombectomy with or without adjuvant thrombolytics in such situations were reported in 7 cases, including the present case [3-5, 10-12]. Interestingly, none of the reported cases showed any intracerebral hemorrhage, and the clinical outcome was good except in two cases $(71 \%)$. Another retrospective single center consecutive registry of septic embolic stroke reported that 5 patients with infective endocarditis received intravenous or IA thrombolysis with or without mechanical thrombectomy, and the clinical outcomes were universally poor [7].

With limited sources of information regarding treatment strategies for patients with septic embolic stroke, intravenous and/or IA thrombolysis might increase the risk of hemorrhagic complications, which may alter clinical outcome. However, the use of mechanical thrombectomy as a first-line treatment rarely increases the chance of hemorrhagic complications. Therefore, despite lacking sufficient evidence regarding treatment options in patients with large vessel occlusions due to infective endocarditis, IA mechanical thrombectomy possibly can be a first-line treatment option in such cases. Also, pathologic confirmation of the retrieved clots can be key evidence in the diagnosis of suspected infective endocarditis and helpful in understanding the mechanism of stroke in patients with infective endocarditis.

\section{Acknowledgement}

We thank Wade Martin of Medical Research International for his critical English revision.

\section{References}

1. Ong E, Mechtouff L, Bernard E, Cho TH, Diallo LL,
Nighoghossian N, et al. Thrombolysis for stroke caused by 


\section{Forced Arterial Suction Thrombectomy of Septic Embolic Middle Cerebral Artery Occlusion Due to Infective Endocarditis}

infective endocarditis: an illustrative case and review of the literature. J Neurol 2013;260:1339-1342

2. Bhuva P, Kuo SH, Claude Hemphill J, Lopez GA. Intracranial hemorrhage following thrombolytic use for stroke caused by infective endocarditis. Neurocrit Care 2010;12:79-82

3. Dababneh H, Hedna VS, Ford J, Taimeh Z, Peters K, Mocco J, et al. Endovascular intervention for acute stroke due to infective endocarditis: case report. Neurosurg Focus 2012;32:e1

4. Sukumaran S, Jayadevan ER, Mandilya A, Sreedharan SE, Harikrishnan S, Radhakrishnan N, et al. Successful mechanical thrombectomy of acute middle cerebral artery occlusion due to vegetation from infective endocarditis. Neurol India 2012;60:239240

5. Kan P, Webb S, Siddiqui AH, Levy EI. First reported use of retrievable stent technology for removal of a large septic embolus in the middle cerebral artery. World Neurosurg 2012;77:591.e1-5

6. Kang DH, Hwang YH, Kim YS, Park J, Kwon O, Jung C. Direct thrombus retrieval using reperfusion catheter of the penumbra system: forced-suction thrombectomy in acute ischemic stroke. AJNR Am J Neuroradiol 2011;32:283-287
7. Walker KA, Sampson JB, Skalabrin EJ, Majersik JJ. Clinical characteristics and thrombolytic outcomes of infective endocarditis-associated stroke. Neurohospitalist 2012;2:87-91

8. Hart RG, Foster JW, Luther MF, Kantar MC. Stroke in infective endocarditis. Stroke 1990;21:695-700

9. Ruttmann E, Willeit J, Ulmer H, Chevtchik O, Hofer D, Poewe W, et al. Neurological outcome of septic cardioembolic stroke after infective carditis. Stroke 2006;37:2094-2099

10. Bain MD, Hussain MS, Gonugunta V, Katzan I, Gupta R. Successful recanalization of a septic embolus with a balloon mounted stent after failed mechanical thrombectomy. $J$ Neuroimaging 2011;21:170-172

11. Toeg HD, Al-Atassi T, Kalidindi N, Iancu D, Zamani D, Giaccone $\mathrm{R}$, et al. Endovascular treatment for cerebral septic embolic stroke. J Stroke Cerebrovasc Dis 2014;23:e375-377

12. Kang G, Yang TK, Choi JH, Heo ST. Effectiveness of mechanical embolectomy for septic embolus in the cerebral artery complicated with infective endocarditis. J Korean Med Sci 2013;28: 1244-1247 